\title{
Lamellar keratoplasty in rabbits using an allogeneic free omental graft and omentum-derived mesenchymal cells associated with the canine amniotic membrane
}

Ceratoplastia lamelar em coelhos usando enxerto de omento alógeno livre e células mesenquimais omentais associadas com membrana amniótica canina

\begin{abstract}
The objective of this research was to evaluate the clinical and microscopic effects in rabbits of lamellar keratoplasty using allogeneic omentum associated with canine amniotic membrane (AM). Rabbits were divided into two groups: one received the allogeneic free omental graft covered with the AM (OM-graft group), while the other received the AM graft containing omental mesenchymal cells (OM-cell group). Clinical signs were evaluated on different postoperative days. After the clinical assessments, the rabbits were euthanized and their corneas were obtained for histopathology and immunohistochemistry (Ki67, marker for proliferation). Both groups showed chemosis, blepharospasm, eye discharge, hyperemia, and corneal opacity/ edema. Neovascularization was observed in the OM-cell group. Histopathological evaluation revealed epithelial islands within the stroma of OM-cell samples. Thirty days after surgery, complete corneal re-epithelialization had occurred in both groups. The OMcell group showed more Ki-67 positive cells. The free omentum and its cells, combined with the AM, contributed to corneal repair, a process that was completed 30 days after lamellar keratoplasty.
\end{abstract}

Séfora Vieira da Silva Gouvêa de Barros ${ }^{\mathrm{I}}$ Marcela Aldrovani ${ }^{\mathrm{I}}$ Luciana Cenço Correa de Lacerda ${ }^{\mathrm{I}}$ Mônica Horr ${ }^{\mathrm{I}}$ Fábio Andrade Marinho ${ }^{\mathrm{I}}$ Tiago Barbalho Lima ${ }^{\mathrm{I}}$ Camila Pinho Balthazar da Silveira ${ }^{\mathrm{I}}$ Fábio Luiz da Cunha Brito Vinícius Bassaneze II Mayra Cunha FlecherII Renato Travassos Beltrame ${ }^{\text {II }}$

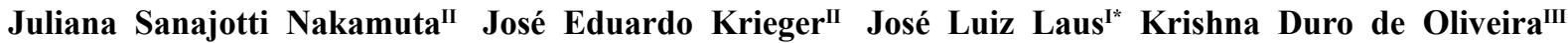

Key words: amniotic membrane, cornea, omentum, progenitor cells, wound healing.

RESUMO

Objetivou-se, com a pesquisa, avaliar os efeitos clínicos e microscópicos da associação do omento de coelho com a membrana amniótica (AM) canina, na ceratoplastia lamelar em coelhos. Dois grupos foram constituidos: um recebeu enxerto de omento alógeno livre, recoberto por AM (grupo OM- graft); o outro recebeu enxerto de AM contendo células mesenquimais derivadas do omento (grupo OM-cell). Manifestações clínicas foram avaliadas em diferentes tempos de pós-operatórios. Após as avaliações clínicas, coelhos foram submetidos à eutanásia e córneas foram colhidas para histopatologia e imunohistoquímica (Ki-67, marcador de proliferação). Relativamente às manifestações clínicas, ambos os grupos apresentaram sinais de quemose, blefarospasmo, secreção ocular, hiperemia e opacidadeledema. Neovascularização foi observada no grupo OM-cell. Avaliações à histopatologia mostraram que uma amostra de OM-cell apresentou ilhas de epitélio dentro do estroma. Aos 30 dias de pós-operatório, observou-se reepitelização corneal completa, em OM-graft e OM-cell. O grupo OM-cell apresentou mais células positivas para Ki-67. O omento livre e suas células, associados à AM, contribuiram para a reparação corneal, que se completou após 30 dias de ceratoplastia lamelar.

Palavras-chave: células progenitoras, córnea, membrana amniotica, omento, reparação tecidual.

\section{INTRODUCTION}

Corneal diseases cause morphofunctional changes of varying pathogenesis. The most significant lesions are those that alter the corneolimbal stromal microenvironment, jeopardizing the survival of the progenitor cells (PCs) (SILVA RICARDO \& GOMES, 2010). Treatment of corneal lesions is expensive, and despite the therapeutic advances of the last 20 years, these diseases are still a socio-economic problem in developing countries.

Transplantation of biomaterials, especially the amniotic membrane (AM), is a viable option for treating corneal lesions resistant to medical therapy (HOLLAND et al., 2015). Previous reports showed that allogeneic or xenogenous AM can be associated with other

\footnotetext{
'Departamento de Clínica e Cirurgia, Faculdade de Ciências Agrárias e Veterinárias (FCAV), Universidade Estadual Paulista (UNESP), Campus de Jaboticabal, 14884-900, Jaboticabal, SP, Brasil. E-mail: jllaus@ffcav.unesp.br. "Corresponding author.

"Instituto do Coração (InCor), Escola de Medicina, Universidade de São Paulo (USP), São Paulo, SP, Brasil.

II'Setor de Patologia, VetCâncer Ltda., São Paulo, SP, Brasil.
} 
tissues and used in ophthalmology. Such a procedure is indicated in cases of deep lesions or limbal deficiency (SILVA RICARDO \& GOMES, 2010). Benefits of combining the AM with other tissues may arise from the increased concentration of soluble molecules that stimulate cell migration from the cell-cell and cell-matrix contact site, and the recruitment of cells with high proliferative activity (DUA et al., 2004).

The characteristics (presence of mesenchymal PCs, growth factors and matrix structural macromolecules) of the omentum suggest that it could be associated with the AM (SHAH et al., 2012; PORZIONATO et al., 2013). In fact, studies were published on the benefits of free omental grafts (AZARI et al., 2010), as well omental progenitor or non-progenitor mesenchymal cells (GOMEZ-GIL et al., 2009), in tissue repair.

The goal of this study was to evaluate the effects in rabbits of lamellar keratoplasty using rabbit omentum associated with xenogenous (canine) AM. The allogeneic free omentum fragments, as well as the omental mesenchymal cells derived, were associated with the AM.

\section{MATERIALS AND METHODS}

Animals

Thirty-two adult male White New Zealander rabbits were included in the research. Two rabbits were used as omentum donors, while the other underwent lamellar keratoplasty combined with transplantation of either free omental graft (OM-graft group) or omental mesenchymal cells (OM-cell group). Canine AMs were used as either cell carriers or patches.

Harvesting the canine amniotic membrane

The AMs were obtained from two dogs that had undergone Cesarean sections. After washing, the AMs were cut into $4 \times 4 \mathrm{~cm}$ sections and stored in a vessel containing 98\% glycerol (Synth, SP, Brazil) at $25^{\circ} \mathrm{C}$ for 30 days prior to use.

Harvesting the rabbit omentum

Two rabbits were premedicated by intramuscular injection of acepromazine $(0.04 \mathrm{mg}$ $\mathrm{kg}^{-1}$; Vetnil, SP, Brazil) combined with tramadol (4mg kg-1; Cristália, SP, Brazil). Anesthesia was then induced intravenously using ketamine (10 $\mathrm{mg} \mathrm{kg}^{-1}$; Cristália) combined with midazolam (0.3 $\mathrm{mg} \mathrm{kg}^{-1}$; Cristália) and maintained using propofol (Virbac, SP, Brazil). Abdominal cavity was approached through a $4-\mathrm{cm}$ ventral midline incision. The greater omentum was located and exteriorized from the abdominal cavity. After it was detached, washed in sterile $0.9 \% \mathrm{NaCl}$, and cut into $3 \times 3 \mathrm{~cm}$ pieces. Some pieces were stored in a vessel containing $98 \%$ glycerol for 30 days prior to use as a free graft, other were used to establish cultures of omental mesenchymal cells.

Isolation and culture of omental mesenchymal cells The cells were isolated according to the protocol described by DANOVIZ et al. (2011). The omentum was incubated with collagenase type IA (0.075\%; Sigma, MO, USA) diluted in Dulbecco's Modified Eagle's medium (DMEM) with a low glucose concentration (Cutilab, SP, Brazil). After centrifugation, the cells were resuspended in DMEM supplemented with $10 \%$ fetal bovine serum (Cutilab) and incubated for 12 hours at $37^{\circ} \mathrm{C}$ in $5 \% \mathrm{CO}_{2}$. The non-adherent cells were discarded, while the adherent cells were cultured for three days at $37^{\circ} \mathrm{C}$ in a humidified chamber $5 \% \mathrm{CO}_{2}$.

Only cells that had been isolated from the third passage (P3) were used in the study. The presence of PCs was confirmed by flow cytometry using antibodies against human CD90 (BD Pharmingen, CA, USA). Approximately $18 \%$ of the cells were CD90-positive.

Transference of omental mesenchymal cells to the amniotic membranes

Fragments of AM were taken from the glycerol, washed using sterile $0.9 \% \mathrm{NaCl}$, and cut into $2 \times 2 \mathrm{~cm}$ pieces. They were then distended in a 24-well culture plate, with the epithelial side faceup, and immersed in $2 \mathrm{~mL}$ of DMEM containing omental mesenchymal cells. Examination using a Neubauer camera demonstrated that approximately $6.42 \times 10^{4}$ cells were transferred to each piece from the AM. The samples were incubated for 24 hours at $37^{\circ} \mathrm{C}$ in a humid chamber containing $5 \% \mathrm{CO}_{2}$.

\section{Lamellar keratoplasty}

Thirty rabbits were premedicated and anesthetized as described for omentum harvesting. Only the right eye of each rabbit was used in the research. Corneas were desensitized using tetracaine drops that contained $0.1 \%$ phenylephrine (Allergan, SP, Brazil). All procedures were performed using an operating microscope (D.F. Vasconcelos, SP, Brazil). Using a $6-\mathrm{mm}$ trephine the cornea was penetrated 
in the paracentral area to a depth of $1 / 3$ of the stromal thickness, creating a recipient bed for implantation of the free-omental graft (Figure 1A) or cells-containing AM (Figure 1B).

Free-omental grafts were confectioned using a 7-mm trephine. After fixation to the corneas using 9-0 mononylon wire in a simple separated suture, the grafts were covered with AM patches. The patchs were placed with the epithelial face not in direct contact with the cornea, so as to cover the omentum, and its edges were sutured to the conjunctival fornix, using 8-0 mononylon in simple interrupted points.

AMs that contained the omental mesenchymal cells were transplanted onto the eyes of 15 rabbits. Cells were placed in contact with the recipient bed, and the AM was sutured using 9-0 mononylon wire in a continuous pattern. No patch was used.

All rabbits were treated using tobramycin eye drops (Alcon, SP, Brazil) every 6 hours for 2 weeks. Tramadol $\left(3 \mathrm{mg} \mathrm{kg} \mathrm{kg}^{-1}\right.$; Cristália) was administered by subcutaneous injection every 20 hours for 5 days. Animals were euthanized on postoperative days 3, 7, 14,30 , or 60 .

Clinical evaluation

Clinical data were collected prior to euthanasia. Chemosis, blepharospasm, ocular discharge, conjunctival hyperemia, corneal opacity/ edema, graft retention, and neovascularization were graded as absent, mild, moderate, or severe (GODOY-ESTEVEZ et al., 2015).

Histopathology and immunohistochemistry

Corneas were harvested on postoperative days $3,7,14,30$, and 60 ; they were fixed using $10 \%$ buffered formaldehyde and embedded in paraffin. Sections $(4-\mu \mathrm{m})$ were stained using hematoxylineosin (HE) or subjected to immunohistochemistry to detect cell proliferation (Ki-67 [clone MIB-1]; DAKO, CA, USA) (CRESTA \& ALVES, 2007). Optimum dilution of the antibody was 1:50. Citrate buffer ( $\mathrm{pH}$ 6.0) was used for antigen retrieval. Histofine Simple Stain ${ }^{\mathrm{TM}}$ MAX PO (Nichirei Inc., WA, USA) and diaminobenzidine (Nichirei Inc) were used to detect primary antibody.

\begin{abstract}
Statistical analysis
Categorical variables were compared using Fisher's exact test. A $P$-value $\leq 0.05$ was considered statistically significant. Cluster analysis was performed to classify the rabbit corneas according to the collections of ocular manifestations that occurred in each postoperative period. Similarities between clinical profiles were measured as the Euclidean distance. All calculations were carried out using software (Minitab Inc., CA, USA).
\end{abstract}

\section{RESULTS AND DISCUSSION}

It is customary to use membranes in lamellar keratoplasty. However, difficulties

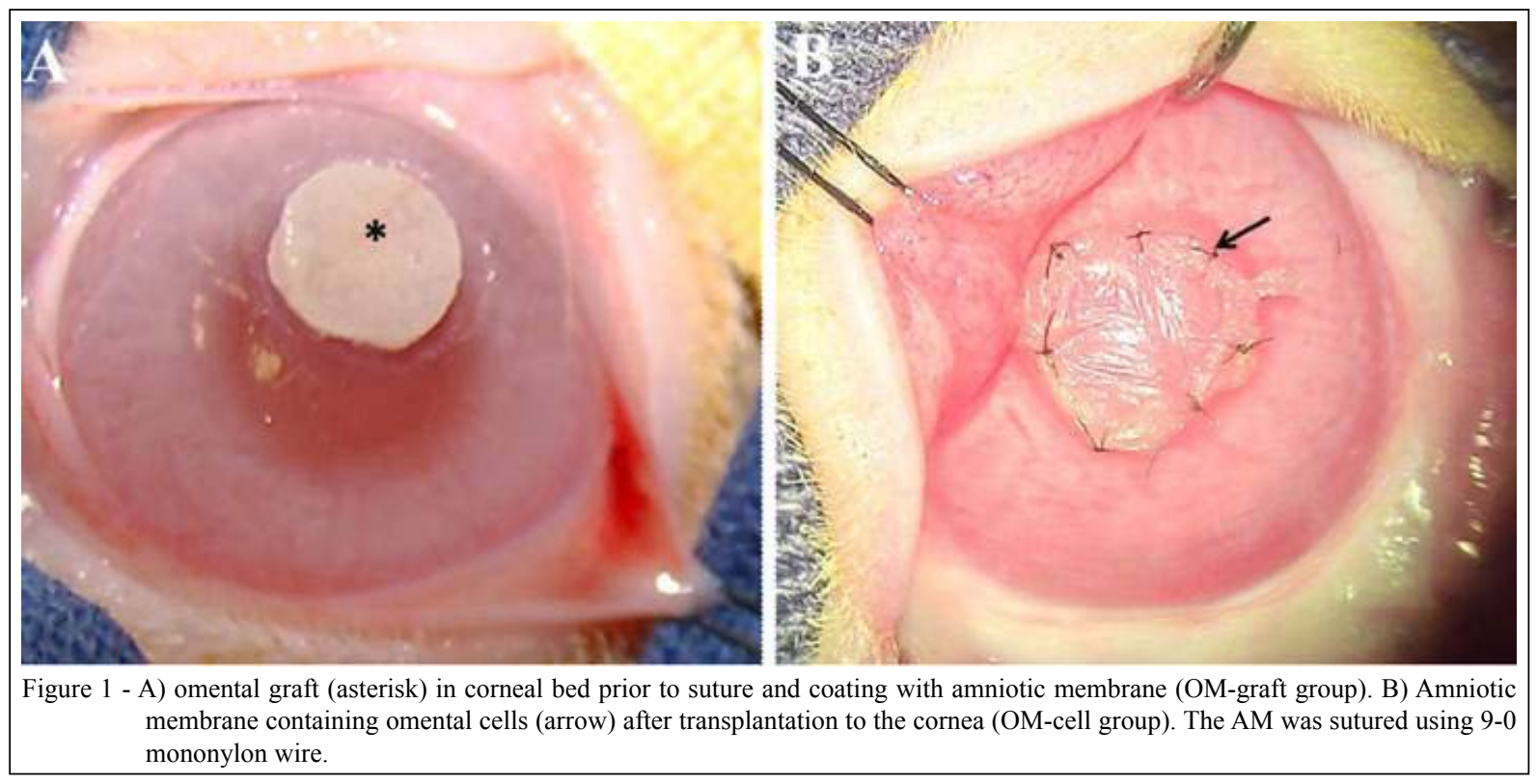

Ciência Rural, v.46, n.10, out, 2016. 
remain as regards, selecting and processing the materials, justifying the search for new options. Biological membranes can be used freshly; however, this reduces the maximum possible interval between harvest and transplantation (MALHOTRA \& JAIN, 2014). Different protocols have been established to preserve biological membranes; namely, storage in glycerin $98 \%$ or cryopreservation.

Many reports have been published on the use of free omentum graft in reconstructive surgery. The omentum is a fragile biomaterial with low mechanical strength (LANGLEYHOBBS et al., 2013); for this reason, a support graft is often used alongside it, as in this study. Due to its immune privilege, the omentum used in such grafting need not be of autogenous origin.

Several authors have advocated using omentum that has been activated by intraperitoneal injection of polydextran particles as a donor source of mesenchymal PCs (SINGH et al., 2008; REQUICHA et al., 2012), rather than the inactived omentum used in this study. In such a procedure, polydextran particles are surrounded by the stem cells after injection. However, because this was the first study to assess omental mesenchymal cells in corneal repair, we used the inactivated form; we will test alternative techniques in the future.

Regarding clinical manifestations, signs of chemosis, blepharospasm, ocular discharge, hyperemia, and corneal opacity/edema were observed. Interesting the OM-graft and OM-cell groups differed only with regard to the occurrence of chemosis, which was observed on day $3(100 \%$ for OM-graft vs. 7.1\% for OM-cell, $P<0.001)$.

About $46.6 \%$ of the eyes in the OM-graft group showed mild-to-moderate blepharospasm on day 3 after surgery. A severe mucous ocular secretion (Figure 2A) was observed on day 3 in $26.6 \%$ of eyes. A mild-to-moderate secretion was detected on days $3(58.3 \%)$ and $14(22.2 \%)$; this had been resolved in subsequent assessments. Hyperemia, which varied from mild to severe, was observed from day 3 (100\%) until day 30 (16.6\%). A moderate-to-severe corneal opacity (Figure 2B) was detected at the beginning of the assessment $(80 \%)$; this had been resolved after 30 days. Dehiscence at the fixing points of the AM and omentum was observed in all animals of the OM-graft group at day 7. Neovascularization was not observed at any of the evaluations.

Mild-to-moderate blepharospasm was detected in eyes in the OM-cell group at the early

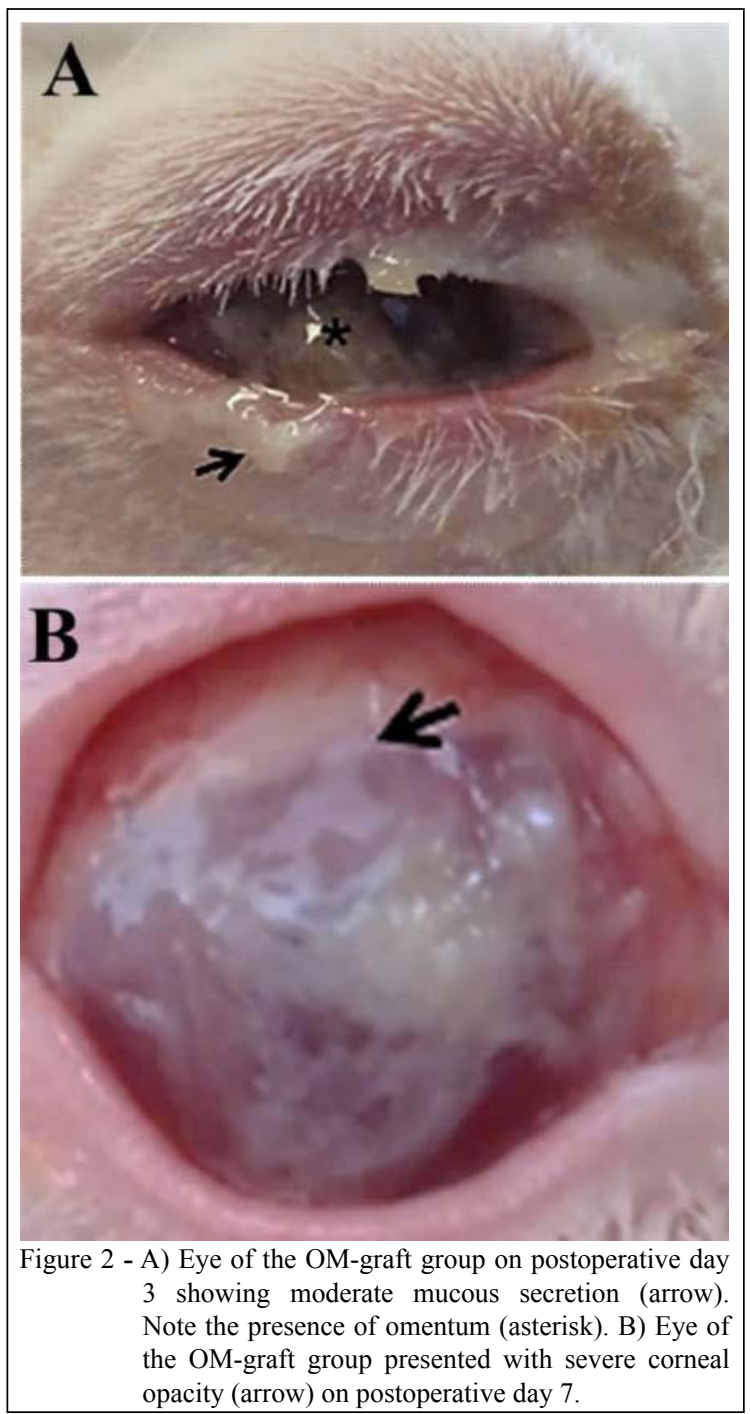

assessment $(78.3 \%$ of eyes at day 3 and $75 \%$ at day 7). Furthermore, a mild, mucous eye discharge (Figure 3A) was observed from day $3(85.7 \%)$ until day $14(66.6 \%)$. Hyperemia, ranging from mild to severe, was present until day $30(16.6 \%)$. Mildto-moderate opacity (Figure 3B) was observed at all assessments, persisting until day 60 in $33.3 \%$ of eyes. Neovascularization was observed after 30 days of assessment (100\%); this was likely caused by the xenogenous AM, as noted by GODOYESTEVES et al., (2015), who found more inflammatory infiltrates and neovascularization when using human AM than when using allogeneic AM, for lamellar keratoplasty in rabbits. In keeping with the possibility that the neovascularization observed in OM-cell group caused AM, no new vessels were detected in the 


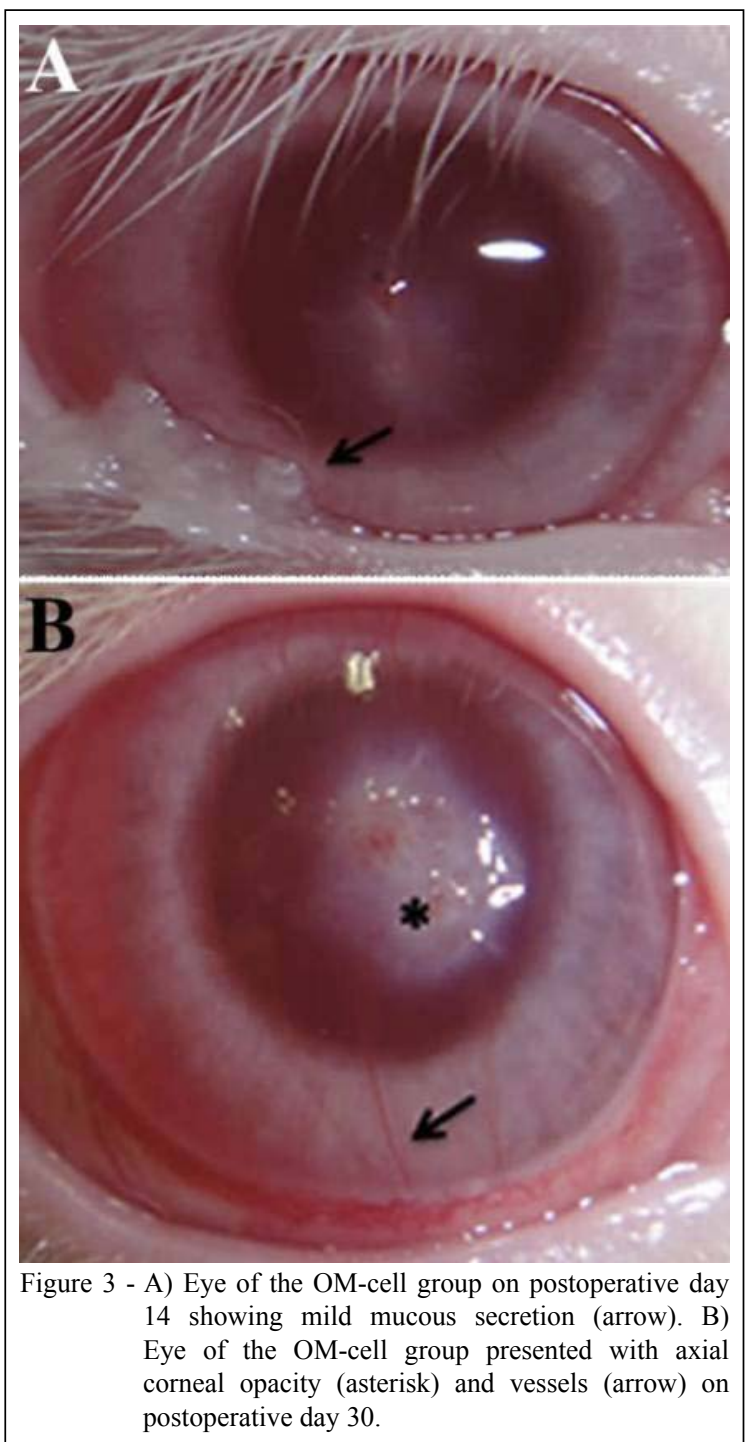

OM-graft group; however, dehiscence did occur. Nonetheless, the neovascularization may also have been caused by the suture material.

Postoperative ocular manifestations were assessed using cluster analysis (MCLACHLAN, 1992); this reduced the subjective interpretation of the results, since individuals from the sample were allocated to subgroups based on the set of the clinical manifestations. Cluster analysis is used in medicine to identify patients who are expected to have the same level of response to treatment (BOUSLAUG, 2007). This is an exploratory statistical method, where the distance (Euclidean) between individuals of the sample is calculated and represented by dendograms. The Euclidean distance is defined as the square root of the sum of the squares of the differences between all the coordinates of the vectors that define each individual in the sample (BOUSLAUG, 2007). The dendogram is a diagram that illustrates the agglomeration of the data into subgroups in a way that the similarity between them is maximal if they belong to the same subgroup, and minimal otherwise. In this study, unified agglomerations of samples were observed, without the formation of subgroups, thereby indicating that the OM-graft and OM-cell individuals were similar over a range of clinical manifestations at different evaluation times (Figure 4A-E).

Due to lack of data on the use of omentum to repair corneal lesion, it was not identified its mechanism of action. In neither group epithelium it was observed lesion areas in any of the animals on postoperative day 3 (Figure 5A). Corneas harvested on postoperative days 7 and 14 showed inflammatory infiltrates, which were more extensive in the OM-graft group (Figure 5B). Similar results have been previously reported and suggested an active wound healing (GODOY-ESTEVES et al., 2015).

On postoperative day 7, a sample from the OM-cell group showed epithelial islands within the stroma (Figure 5C). This result could be attribute to the movement of corneal epithelial cells into the AM during suturing (BARBOSA et al., 2013), or to an active process of cell recruitment called epithelial-mesenchymal transition (MICALLIZZI et al., 2010).

At day 30, the corneas of both groups had a stratified epithelium (Figure 5D and E) coating the lesion areas. The degree of stratification observed suggests the biosynthesis of adhesion molecules. In the OM-cell group, vessels were observed in the stroma (Figure 5F).

With regard to epithelial cell proliferation, strong Ki-67 expression was observed in the OM-cell group during the final stages of corneal repair process (Figure 5G). The source of the proliferative cells was not identified; however, the Ki-67 positive cells may correspond to differentiating cells in the cornea itself, the corneal limbus or the conjunctival fornix.

\section{CONCLUSION}

The free omentum and its cells, combined with the AM, contributed to corneal repair, a process that was completed 30 days after lamellar keratoplasty. The mechanism of action of the omentum remains to be ascertained in future studies. 
A

distance

1.73

0.58

0.00

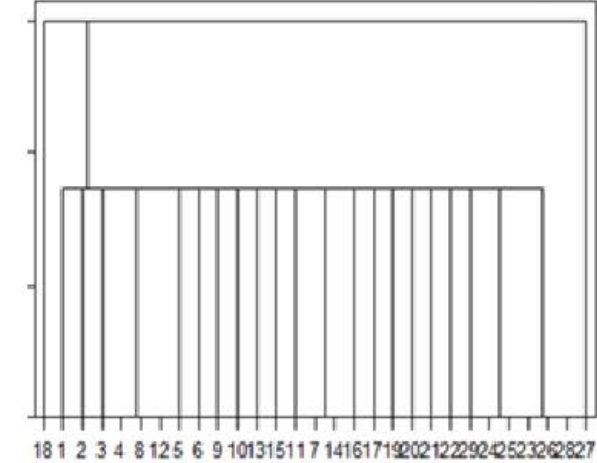

rabbits

C

distance

1.73

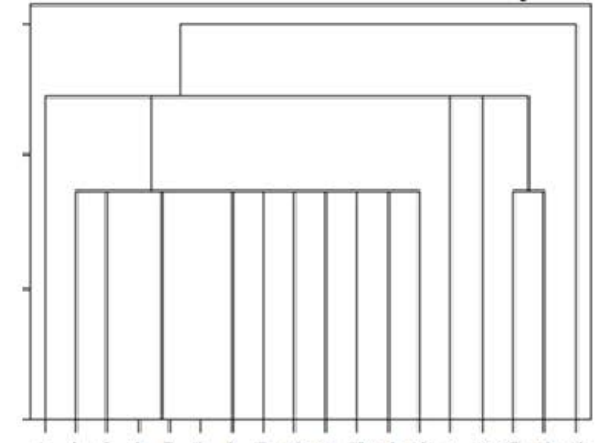

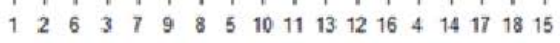

rabbits

E

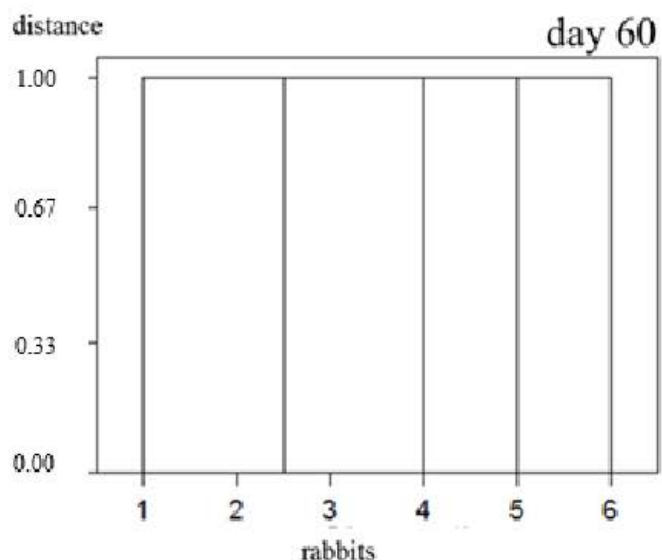

B

day 3 distance

day 7

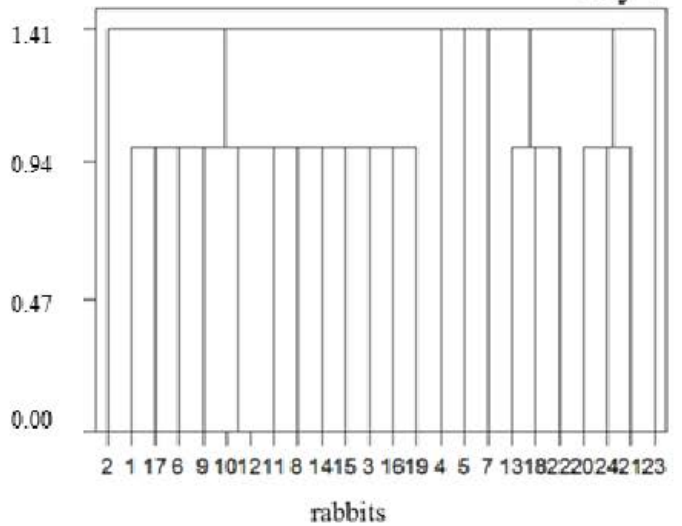

D

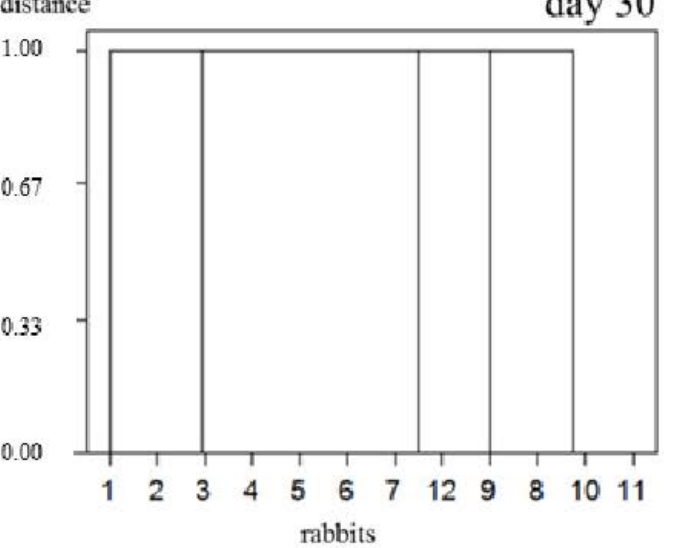

Figure 4 - Dendrograms representative of the groups and Euclidean distances between the corneas of the rabbits used in this study, taking into consideration the clinical manifestations observed during the temporal evolution of the lamellar keratoplasty. In each graph (A-E), the first half of the total number of corneas evaluated corresponds to the OM-graft group. The second half corresponds to the OM-cell group. 


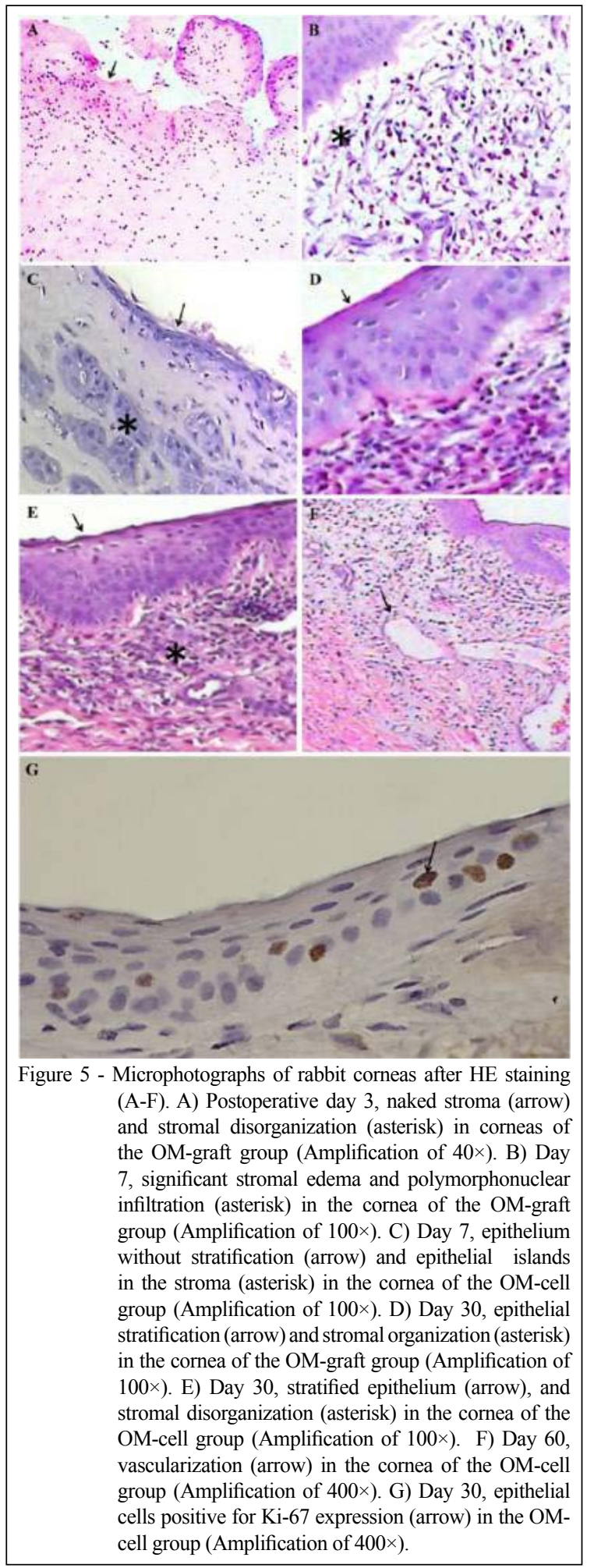

\section{ACKNOWLEDGEMENTS}

This study was supported by the São Paulo Research Foundation (FAPESP Proc. 2011/17665-0, 2012/17308-5) and the
Conselho Nacional de Desenvolvimento Científico e Tecnológico (CNPq) (Proc. 300833/2010-5).

\section{BIOETHICS AND BIOSSECURITY COMMITTE APPROVAL}

The protocol of this study (No. 017001/12) was approved by the Ethical Committee on Animal Research of Faculdade de Ciências Agrárias e Veterinárias (FCAV), Universidade Estadual Paulista (UNESP).

\section{REFERENCES}

AZARI, O. et al. Effect of autologous omental free graft on wound healing process in experimental cervical oesophagus incision in dog: short-term preliminary histopathological study. Comparative Clinical Pathology, v.21, p.559-563, 2012. Available from: <http://download.springer.com/static/pdf/906/ art\%253A10.1007\%252Fs00580-010-1130-2.pdf $>$. Accessed: Aug. 18, 2014. doi:10.1007/s00580-010-1130-2.

BARBOSA, A. et al. Lamelar keratoplasty in dogs using equine amniotic membrane. Clinical and morphological study. Brazilian Journal of Veterinary Research and Animal Science, v.50, p.211-219, 2013. Available from: <http://www.revistas.usp. br/bjvras/article/view/64593>. Accessed: Oct. 30, 2014. doi:10.11606/issn. 1678-4456.v50i3p211-219.

BOUSLAG, S.E. Encyclopedia of epidemiology. New York: SAGE Publications, 2007. V.1.

CRESTA, F.B.; ALVES, M.R. Evaluation of the corneal epithelium kinetics using cell proliferation markers. Arquivos Brasileiros de Oftalmologia, v.70, p.953-960, 2007. Available from: <http://www.scielo.br/scielo.php?pid=S000427492007000600013\&script $=$ sci_arttex $>$. Accessed: Dec. 5, 2014. doi: 10.1590/S0004-27492007000600013.

DANOVIZ, M.E. et al. Adipose tissue-derived stem cells from human and mice differ in proliferative capacity and genome stability in long term cultures. Stem Cells and Development, v.20, p.661-670, 2011. Available from: <http://online.liebertpub. com/doi/abs/10.1089/scd.2010.0231>. Accessed: Apr. 23, 2014. doi: $10.1089 /$ scd.2010.0231.

DUA, H.S. et al. The amniotic membrane in ophthalmology. Survey of Ophthalmology, v.49, p.51-77, 2004. Available from: $<$ http://www. surveyophthalmol.com/article/S0039-6257(03)00126-7/abstract $>$. Accessed: Oct. 28, 2013. doi: 10.1016/j.survophthal.2003.10.004.

GODOY-ESTEVES, C.A.L. et al. Lamellar keratoplasty in rabbits using human and rabbit amniotic membrane grafts: a comparative study. Veterinary Ophthalmology, v.18, p.191-197, 2015. Available from: <http://onlinelibrary.wiley.com/doi/10.1111/ vop.12109/full>. Accessed: Aug. 5, 2015. doi: 10.1111/vop.12109.

GÓMEZ-GIL, V. et al. Characterizing omental adhesions by culturing cells isolated from a novel in vivo adhesion model. Wound Repair and Regeneration, v.17, p.51-61, 2009. Available from: <http://onlinelibrary.wiley.com/doi/10.1111/ j.1524-475X.2008.00441.x/abstract>. Accessed: Jan. 18, 2015. doi: 10.1111/j.1524-475X.2008.00441.x.

HOLLAND, E.J. et al. Ocular Surface Disease: Cornea, Conjunctiva and Tear Film. Rio de Janeiro: Saunders Elsevier, 2015. V.1.

Ciência Rural, v.46, n.10, out, 2016. 
LANGLEY-HOBBS. J. et al. Feline soft tissue and general soft. UK: Saunders Elsevier, 2013. V.1.

MALHOTRA, C.; JAIN, AK. Human amniotic membrane transplantation: different modalities of its use in ophthalmology. World Journal Transplantation. v.4, p.111-121, 2014. Available from: <http://www.ncbi.nlm.nih.gov/pmc/articles/PMC4094946>. Accessed: Jan. 28, 2016. doi: 10.5500/wjt.v4.i2.111

MCLACHLAN, G.J. Cluster analysis and related techniques in medical research. Statistical Methods in Medical Research, v.1, p.27-48, 1992. Available from: <http://www.ncbi.nlm.nih.gov/ pubmed/1341650>. Accessed: Feb. 3, 2015.

MICALLIZZI, D.S. et al. Epithelial-mesenchymal transition in cancer: parallels between normal development and tumor progression. Journal of Mammary Gland Biology and Neoplasia, v.15, p.117-134, 2010. Available from: <http://link springer.com/article/10.1007\%2Fs10911-010-9178-9>. Accessed: Sept. 9, 2014. doi:10.1007/s10911-010-9178-9.

PORZIONATO, A. et al. Decellularized omentum as novel biologic scaffold for reconstructive surgery and regenerative medicine. European Journal Histochemistry, v.57, p.e4, 2013. Available from: <http://www.ncbi.nlm.nih.gov/pmc/articles/PMC3683611/pdf/ ejh-2013-1-e4.pdf $>$. Accessed: Oct. 3, 2014. doi:10.4081/ejh.2013.e4.
REQUICHA, J.F. et al. Effect of anatomical origin and cell passage number on the stemness and osteogenic differentiation potential of canine adipose-derived stem cells. Stem Cell Reviews, v.8, p.1211-1222, 2012. Available from: <http:// link.springer.com/article/10.1007\%2Fs 12015-012-9397-0>. Accessed: Apr. 5, 2014. doi: 10.1007/s12015-012-9397-0.

SHAH, S. et al. Cellular basis of tissue regeneration by omentum. PlosOne, v.7, p.0038368, 2012. Available from: $<$ http://journals.plos.org/plosone/article?id=10.1371/ journal.pone.0038368>. Accessed: Jun. 3, 2015. doi:10.1371/ journal.pone. 0038368

SILVA RICARDO, J.R.; GOMES, J.A.P. Use of stem cells cultured ex vivo for ocular surface reconstruction. Arquivos Brasileiros de Oftalmologia, v.73, p.541-547, 2010. Available from: <http://www.scielo.br/scielo.php?pid=S0004$27492010000600017 \&$ script $=$ sci arttext $>$. Accessed: Aug. 28, 2013. doi: 10.1590/S0004-27492010000600017.

SINGH, A.K. et al. Stromal cells cultured from omentum express pluripotent markers, produce high amounts of VEGF, and engraft to injured sites. Cell Tissue Research, v.332, p.81-88, 2008. Available from: <http://link.springer.com/ article/10.1007\%2Fs00441-007-0560-x>. Accessed: Apr. 3, 2015. doi: 10.1007/s00441-007-0560-x. 


\section{ERRATUM}

Artigo "Lamellar keratoplasty in rabbits using an allogeneic free omental graft and omentum-derived mesenchymal cells associated with the canine amniotic membrane" publicado no fascículo v46n10 de outubro de 2016 da Ciência Rural, onde se lia:

\footnotetext{
"Séfora Vieira da Silva Gouvêa de Barros $^{\mathrm{I}}$ Marcela Aldrovani ${ }^{\mathrm{I}}$ Luciana Cenço Correa de Lacerda ${ }^{\mathrm{I}}$ Mônica Horr ${ }^{\mathrm{I}}$ Fábio Andrade Marinho ${ }^{\mathrm{I}}$ Tiago Barbalho Lima ${ }^{\mathrm{I}}$ Camila Pinho Balthazar da Silveira ${ }^{\mathrm{I}}$ Fábio Luiz da Cunha Brito Vinícius Bassaneze ${ }^{\mathrm{II}}$ Mayra Cunha Flecher ${ }^{\mathrm{II}}$ Renato Travassos Beltrame ${ }^{\mathrm{II}}$ Juliana Sanajotti Nakamuta ${ }^{\mathrm{II}}$ José Eduardo Krieger ${ }^{\mathrm{II}}$ José Luiz Laus ${ }^{\mathrm{*}}$,
}

"Departamento de Clínica e Cirurgia, Faculdade de Ciências Agrárias e Veterinárias (FCAV), Universidade Estadual Paulista (UNESP), Campus de Jaboticabal, 14884-900, Jaboticabal, SP, Brasil. E-mail: jllaus@fcav.unesp.br. "Corresponding author.

IIInstituto do Coração (InCor), Escola de Medicina, Universidade de São Paulo (USP), São Paulo, SP, Brasil.”

leia-se:
"Séfora Vieira da Silva Gouvêa de Barros ${ }^{\mathrm{I}}$ Marcela Aldrovani $^{\mathrm{I}}$ Luciana Cenço Correa de Lacerda ${ }^{\mathrm{I}}$ Mônica Horr ${ }^{\mathrm{I}}$ Fábio Andrade Marinho ${ }^{\mathrm{I}}$ Tiago Barbalho Lima $^{\mathrm{I}}$ Camila Pinho Balthazar da Silveira ${ }^{\mathrm{I}}$ Fábio Luiz da Cunha Brito ${ }^{\mathrm{I}}$ Vinícius Bassaneze ${ }^{\text {II }}$ Mayra Cunha Flecher ${ }^{\text {II }}$ Renato Travassos Beltrame ${ }^{\text {II }}$ Juliana Sanajotti Nakamuta ${ }^{\text {II }}$ José Eduardo Krieger ${ }^{\mathrm{II}}$ José Luiz Laus ${ }^{\mathrm{I}^{*}}$ Krishna Duro de Oliveira ${ }^{\mathrm{III}}$ "

"Departamento de Clínica e Cirurgia, Faculdade de Ciências Agrárias e Veterinárias (FCAV), Universidade Estadual Paulista (UNESP), Campus de Jaboticabal, 14884-900, Jaboticabal, SP, Brasil. E-mail: jllaus@fcav.unesp.br. "Corresponding author.

"Instituto do Coração (InCor), Escola de Medicina, Universidade de São Paulo (USP), São Paulo, SP, Brasil.

"I'Setor de Patologia, VetCâncer Ltda., São Paulo, SP, Brasil."

Para a versão correta, acesse:

http://www.scielo.br/pdf/cr/v46n10/1678-4596-cr-0103_8478cr20151348.pdf 